\title{
Designing Learning Game for Human Digestive System Based on Motion Sensors
}

\author{
Gregorius Alvin Raditya Santoso, Albertus Dwi Yoga Widiantoro, Ridwan Sanjaya \\ Department of Information System, Faculty of Computer Science, \\ Soegijapranata Catholic University, Semarang, Indonesia \\ gregoriusalvin24@gmail.com,yoga@unika.ac.id,ridwan@unika.ac.id
}

\begin{abstract}
Nowaday rapid development of communication and information technology also influences the sector of education. The main activity in the education process is learning. Learning is a process of interaction between students and their environment, leading to better behavior changes [1].

One of the learning subjects that students must learn is science. But Indonesian student's scientific literacy is still low [2]. Students still consider science subjects difficult and boring [3]. One learning material that is classified difficult is the human digestive system [4]. Therefore a solution is needed to make interesting learning one of them by using learning media.
\end{abstract}

Learning media that can be used for the solution is game based on motion sensors. By using games, students will be happy to accept the learning process. Based on a survey conducted on 30 respondents of junior high school students in the Semarang, it turns out that the game used as a human digestive system learning media is able to provide positive results. Through this game students can understand the digestive system material and more enthusiastic in learning.

Keywords- Game, Human Digestive System, Learning Media, Motion Sensor

\section{INTRODUCTION}

In the globalization era, technological developments have also influenced the education sector. In education the main activity carried out is learning. Learning is a process of interaction between students and their environment, leading to better behavior changes [1].
One of the subjects that must be learned by students in the class is science. But student's science literacy in Indonesia is still relatively low [2], besides students tend to feel that these subjects are difficult and boring. The learning system applied by the teacher also tends to be monotonous and does not involve students [3].

In science, one of the difficult learning materials is the human digestive system [4]. There are still many students who score below the minimum score requirement for this learning material [5]. Therefore a solution is needed to make learning process in the classroom interesting so that students are easy to understand and enthusiastic in learning.

One solution that can be used is using learning media. Hamalik stated that learning media is a tool, method and technique used to make effective communication and interaction between teachers and students more effective in the learning process in the classroom [6]. One of the learning media that comes along with the development of technology is games.

Based on the research conducted by Harsono about the influence of playing games on adolescent development, there are some positive effects of playing games, among others, as a means of learning, facilitating problem solving, fostering curiosity, increasing insight, learning, and more ambitious [7]. So that the game is able to help students in the learning process. In addition, if combined with motion sensors, the game will increase student involvement and interaction in the classroom [8]. Therefore it is necessary to design game for learning human digestive system based on 
motion sensors to make it easier for students to understand the material and be enthusiastic in the learning process.

\section{METHOD}

\section{A. Human Digestive System}

Digestion is the process of breaking down or dividing food into small molecules, so it can be absorbed by the human body. Food molecules that have been sent by blood then enter the cell. Molecules that are not needed by the body will be released through the excretion system, while non-digestible food in the form of feces will be released through the anus, this process is called defecation.

The human digestive system consists of the main organs in the form of the digestive tract and accessory organs. The digestive tract is the channel through which food begin from the mouth, esophagus, stomach, small intestine, large intestine, rectum, and end in the anus [9].

\section{B. Game}

Games are an activity to solve problems, in a fun way, game also makes players find pleasure when played. Games that can make players actively participate and have the right number of challenges are good games [10]

\section{Learning Media}

Media in the context of learning media is a tool or intermediary that connects the instructor and his students. Then the learning media can be interpreted as everything that can be used to stimulate attention, emotions, feelings, thoughts, skills and abilities of a person so that it supports the occurrence of learning processes both one direction and more [11].

\section{Educational Game}

Educational game is a game specifically designed to teach students a particular learning, developing concepts, understanding and guiding in training their abilities, and motivating students to play them [12].

\section{E. Unity}

Unity is an easy-to-use game engine. Unity supports the use of three types of scripts, namely C\#, javascript and boo [10]. Unity can be developed on Microsoft Windows and Mac OS X. Applications developed with Unity can be run on
Windows, Mac, Xbox 360, Playstation 3, Ipad, Iphone, and Android devices [13].

Unity as a game engine is often used also for the development of educational games and interactive learning media, such as making bamboo music education games [10], developing educational novels for environmental study curriculums entitled "Adventures in the Guadiana River" [13] and android learning media for writing uses 2D unity [14].

\section{F. Kinect}

Kinect is a Microsoft product that was originally created specifically for Xbox 360 devices, which introduced the main features of motion gaming technology. Motion gaming can make players interact when playing games without using a game controller. So by using kinect, players can play games simply by using hand movements or other body movements [15].

Kinect can be used as a tool in the learning process, because it has the ability to create interesting and fun interactions, while also increasing student motivation, and promoting multimedia learning [8].

\section{G. Research Methodology}

The design of the game begins with a literature study where the author collects references from journals, articles, and books of human digestive system and the use of games as learning media. After that, it is continued by observing and trying out games and interactive learning media that discuss the digestive system in humans. Then carried out the implementation of the human digestive system material in each organ into several stages. And give each stage a challenge that is in accordance with the digestive process in the organ. In the implementation of the learning material it was decided that this game will be divided into 6 stages.

Furthermore, making a game prototype using Unity with the C \# programming language, the initial stage of development starts from making gameplay simulations that still use the keyboard and mouse buttons, not yet using the Kinect motion sensor.After the basic system of the game prototype 
works, then the implementation is done using the Kinect sensor. In the implementation process, after the gameplay has finished, a trial is carried out to find out the bugs or errors in the game. After a bug or error is corrected, the game can be used for research. The study was conducted by conducting trials and distributing post test questionnaires to 30 junior high school students in Semarang. The flow of development of game as human digestive systems learning media based on motion sensors can be seen in Figure. 1.
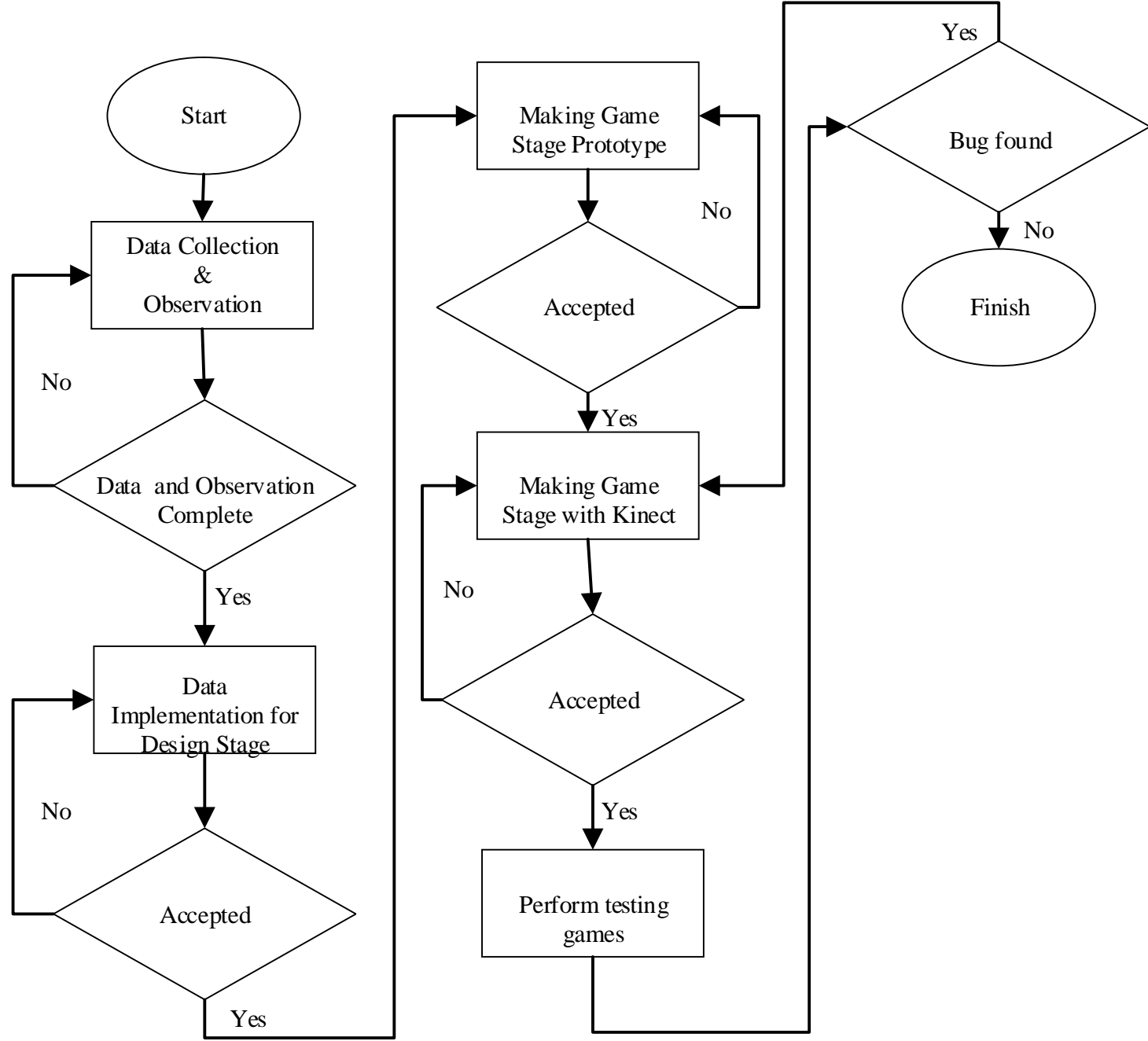

Figure 1. Game Development Flowchart

\section{RESULTS AND DISCUSSION}

After the design and development of the game is complete. Then a trial was conducted on 30 students from several junior high schools in Semarang city and a posttest questionnaire was distributed related to this game for human digestive system learning media based on motion sensor. Figure 2 is an example of the appearance of gameplay in stage 1.

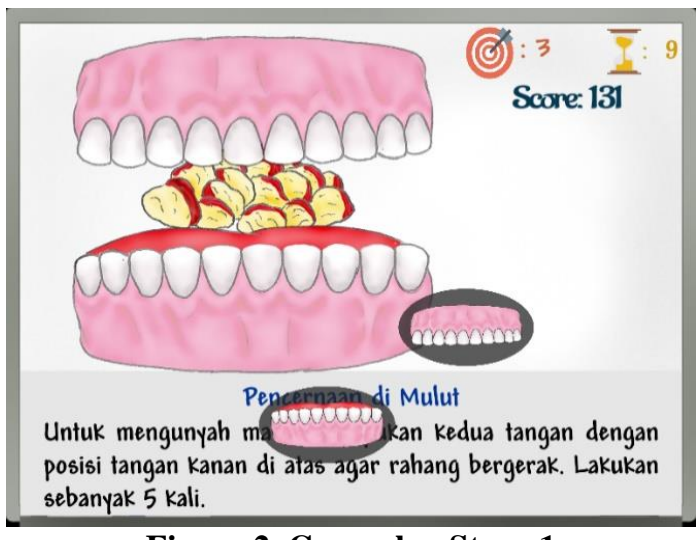

Figure 2. Gameplay Stage 1 
Based on the distribution of the questionnaire from the easiness of playing the game for learning human digestive system based on motion sensor, as many as $3.3 \%$ of students strongly disagree that this game is easy to play. Then $16.7 \%$ of students did not agree. Which states neutral as much as $46.7 \%$, and students who agree at $20 \%$. A total of $13.3 \%$ of students stated strongly agree that this game is easy to play. From the results that can be seen in Table 1 it can be stated that this game is quite easy to play.

Table 1. Easiness of Playing the Game

\begin{tabular}{|c|c|c|}
\hline Option & Frequency & Percentage \\
\hline Strongly disagree & 1 & 3,3 \\
\hline Disagree & 5 & 16,7 \\
\hline Neutral & 14 & 46,7 \\
\hline Agree & 6 & 20,0 \\
\hline Strongly Agree & 4 & 13,3 \\
\hline Total & 30 & 100,0 \\
\hline
\end{tabular}

Next from the player's understanding of the instructions in the game. As many as $10 \%$ of students do not agree that they understand the instructions in the game. Then as many as $26.7 \%$ of students stated neutral. Students who agree are $33.3 \%$ and strongly agree to be chosen by $30 \%$ of students. From the results as in Table 2 it can be stated that students already understand the instructions in this game.

Table 2. Understanding the Game Instruction

\begin{tabular}{|c|c|c|}
\hline Option & Frequency & Percentage \\
\hline Strongly Disagree & 0 & 0 \\
\hline Disagree & 3 & 10 \\
\hline Neutral & 8 & 26,7 \\
\hline Agree & 10 & 33,3 \\
\hline Strongly Agree & 9 & 30 \\
\hline Total & 30 & 100,0 \\
\hline
\end{tabular}

Then in terms of pleasure when playing the game. As many as 3.3\% of respondents strongly disagree to get pleasure when playing games. Furthermore, $10 \%$ of students stated that they did not agree. A total of $26.67 \%$ of students stated neutral. Students who agreed were $36.67 \%$ and strongly agreed as much as $23.3 \%$. From the results in Table 3, it can be stated that this game is quite pleasant for the majority of students who tried it.
Table 3. Pleasure while Playing Game

\begin{tabular}{||c|c|c|}
\hline Option & Frequency & Percentage \\
\hline Strongly Disagree & 1 & 3,3 \\
\hline Disagree & 3 & 10 \\
\hline Neutral & 8 & 26,7 \\
\hline Agree & 11 & 36,7 \\
\hline Strongly Agree & 7 & 23,3 \\
\hline Total & 30 & 100,0 \\
\hline
\end{tabular}

Based on the interest in visual display applied in the game. $6.7 \%$ of respondents strongly disagree and $6.7 \%$ of respondents also disagree that they feel interested in the visual appearance of the game. Furthermore, $26.7 \%$ of students stated neutral. $33.3 \%$ of students felt agreed that the visual appearance of the game was interesting. Respondents who chose strongly agreed as much as $26.7 \%$. From the results in Table 4, it can be stated that the visual appearance applied to the game has appealed to the majority of students who tried it.

Table 4. Interest in the Appearance of the Game

\begin{tabular}{||c|c|c|}
\hline Option & Frequency & Percentage \\
\hline Strongly Disagree & 2 & 6,7 \\
\hline Disagree & 2 & 6,7 \\
\hline Neutral & 8 & 26,7 \\
\hline Agree & 10 & 33,3 \\
\hline Strongly Agree & 8 & 26,7 \\
\hline Total & 30 & 100,0 \\
\hline
\end{tabular}

Then in terms of the respondent's interest in the sound effects used in the game. 6.7\% of students stated strongly disagree. Furthermore, $13.3 \%$ of students stated they did not agree. As many as $43.3 \%$ chose neutral. As many as $26.7 \%$ of students stated that they were interested in the sound effect in the game, and as many as 10\% stated strongly agree. From the acquisition of answers to the questionnaire respondents in Table 5. it can be stated that the sound effects applied to the game are quite interesting for students.

Table 5. Interest in Game Sound Effect

\begin{tabular}{||c|c|c|}
\hline Option & Frequency & Percentage \\
\hline Strongly Disagree & 2 & 6,7 \\
\hline Disagree & 4 & 13,3 \\
\hline Neutral & 13 & 43,3 \\
\hline Agree & 8 & 26,7 \\
\hline Strongly Agree & 3 & 10 \\
\hline Total & 30 & 100,0 \\
\hline
\end{tabular}


Furthermore, in terms of interest in the challenges contained in the game. As many as $3.3 \%$ of students strongly disagree and $20 \%$ of students disagree that the challenges in this game are interesting. Then $33.3 \%$ of students choose neutral. As many as $30 \%$ of students agree that the game challenges are interesting. Respondents who voted strongly agreed at $13.3 \%$. So from the results of Table 6 it can be stated that the challenges in the game are quite interesting.

Table 6. Interest in Game Challenges

\begin{tabular}{|c|c|c|}
\hline Option & Frequency & Percentage \\
\hline Strongly Disagree & 1 & 3,3 \\
\hline Disagree & 6 & 20 \\
\hline Neutral & 10 & 33,3 \\
\hline Agree & 9 & 30 \\
\hline Strongly Agree & 4 & 13,3 \\
\hline Total & 30 & 100,0 \\
\hline
\end{tabular}

Next in terms of understanding the learning material of the human digestive system in the game. $3.3 \%$ of students stated strongly disagree and did not agree that they understood the material. Then as many as $26.7 \%$ chose neutral. Respondents who chose agreed as much as $46.7 \%$ of students and those who voted strongly agreed at $20 \%$. From Table 7 it can be concluded that students have understood the material of the human digestive system found in this learning game.

Table 7. Understanding Learning Material in Game

\begin{tabular}{|c|c|c|}
\hline Option & Frequency & Percentage \\
\hline Strongly Disagree & 1 & 3,3 \\
\hline Disagree & 1 & 3,3 \\
\hline Neutral & 8 & 26,7 \\
\hline Agree & 14 & 46,7 \\
\hline Strongly Agree & 6 & 20 \\
\hline Total & 30 & 100,0 \\
\hline
\end{tabular}

Then from the impact of playing a game that makes students more enthusiastic about learning. 3.3\% said they strongly disagree. Furthermore $6.7 \%$ of students felt they did not agree that they were more enthusiastic about learning. Respondents who stated neutral were $20 \%$. Students who feel agree as much as $46.7 \%$ and those who strongly agree are $23.3 \%$. Based on the results of Table 8 it can be stated that the majority of students feel they are more enthusiastic about learning when playing this game.

Table 8. Level of Enthusiasm for Learning

\begin{tabular}{||c|c|c|}
\hline Option & Frequency & Percentage \\
\hline Strongly Disagree & 1 & 3,3 \\
\hline Disagree & 2 & 6,7 \\
\hline Neutral & 6 & 20 \\
\hline Agree & 14 & 46,7 \\
\hline Strongly Agree & 7 & 23,3 \\
\hline Total & 30 & 100,0 \\
\hline
\end{tabular}

Based on respondents' interest in playing the game again, $3.3 \%$ of students strongly disagree that they want to play the game again. Then as many as $10 \%$ of students expressed disagreement. A total of $26.7 \%$ of students stated neutral. Furthermore, those who agreed were $26.7 \%$ and those who stated strongly agreed were $33.3 \%$. From Table 9 we can see that the majority of students still have an interest in playing this game again.

Table 9. Interest in Playing Game Again

\begin{tabular}{||c|c|c|}
\hline Option & Frequency & Percentage \\
\hline Strongly Disagree & 1 & 3,3 \\
\hline Disagree & 3 & 10 \\
\hline Neutral & 8 & 26,7 \\
\hline Agree & 8 & 26,7 \\
\hline Strongly Agree & 10 & 33,3 \\
\hline Total & 30 & 100,0 \\
\hline
\end{tabular}

\section{CONCLUSIONS}

Learning game for human digestive system based on the motion sensor has several factors that are able to influence prospective game players to play this game, among others, the ease of playing the game, attractive visual appearance, sound effect of the game, the challenges that contained in the game, the pleasure gained when playing games, and easy instructions for playing the game. Besides this game is able to have a positive impact on the player. $66.67 \%$ of students stated that they were able to understand the digestive system learning material in the game. Furthermore, $70 \%$ of students also feel more enthusiastic in learning when playing this game as learning media.

\section{REFERENCES}

[1] Ismail, M. R. Jura, and L. M.. Alibasyah, "Meningkatkan Hasil 
Belajar Siswa Kelas V SDN Mimbala Pada Pokok Bahasan Proses Pencernaan Melalui Penerapan Pembelajaran Quantum Teaching," $J$. Kreat. Tadulako Online, vol. 5, no. 10, pp. 182-193, 2008.

[2] Y. Yuliati, "Literasi Sains Dalam Pembelajaran IPA," J. Cakrawala Pendas, vol. 3, no. 2, pp. 21-28, 2017.

[3] S. Siagian and P. Tanjung, "Pengaruh Strategi Pembelajaran dan Gaya Belajar Terhadap Hasil Belajar IPA Kelas VIII Siswa SMP Negeri 1 Dolok Panribuan," J. Teknol. Pendidik., vol. 5, no. 2, pp. 193-208, 2012.

[4] R. Setiyaningrum, "Pembuatan Media Pembelajaran Ilmu Pengetahuan Alam Untuk Kelas Viii ( Delapan ) Sistem Pencernaan Manusia Pada Sekolah Menengah Negeri 2 Geyer Kabupaten Grobogan," Semin. Ris. Unggulan Nas. Inform. dan Komput. FTI UNSA 2013, vol. 2, no. 1, pp. 79-84, 2013.

[5] T. Lukitaningsih, "Peningkatan Pencapaian Kompetensi Siswa Kelas Viii G Smp Negeri 2 Paron Pada Materi Sistem Pencernaan Manusia Dengan Pendekatan Saintifik Melalui Media Puzzle," Florea J. Biol. dan Pembelajarannya, vol. 2, no. 1, pp. 512, 2015.

[6] M. S. Aksha, "Penggunaan Media Gambar Dalam Peningkatan Hasil Belajar Konsep Sistem Pencernaan Makanan Manusia Pada Siswa Kelas V SD Negeri Kota Lintang Kuala Simpang Kabupaten Aceh Tamiang," JIPSA, vol. 3, no. 1, pp. 17-21, 2016.

[7] A. Latubessy, "Hubungan Antara Adiksi Game Terhadap Keaktifan Pembelajaran Anak Usia 9-11 Tahun," Simetris, vol. 7, no. 2, pp. 687-692, 2016.

[8] H. J. Hsu, "The Potential of Kinect in Education," Int. J. Inf. Educ. Technol., vol. 1, no. 5, pp. 365-370, 2013.

[9] dan M. S. Siti Zubaidah, Susriyati Mahanal, Lia Yuliati, I Wayan Dasna, Ardian A. Pangestuti, Dyne R. Puspitasari, Hamim T. Mahfudhillah,
Alifa Robitah, Zenia L. Kurniawati, Fatia Rosyida, Ilmu Pengetahuan Alam. Jakarta: Pusat Kurikulum dan Perbukuan, Balitbang, Kemendikbud., 2017.

[10] M. Pratama, A. Sinsuw, V. Tulenan, and S. Sentinuwo, "Prototipe Game Musik Bambu Menggunakan Engine Unity 3D," E-journal Tek. Inform., vol. 4, no. 2, pp. 1-6, 2014.

[11] D. Runtulalu et al., "Media Interaktif Pembelajaran Sistem Pencernaan," no. 031.

[12] D. Novaliendry, "Aplikasi Game Geografi Berbasis Multimedia Interaktif (Studi Kasus Siswa Kelas IX SMPN Rao)," J. Teknol. Dan Pendidik., vol. 6, no. 2, pp. 106-118, 2013.

[13] M. Figueiredo and J. Bidarra, "The Development of a Gamebook for Education," Procedia Comput. Sci., vol. 67, no. Dsai, pp. 322-331, 2015.

[14] A. F. Adiqro, "Aplikasi Pembelajaran Menulis Permulaan Berbasis Android Menggunakan Unity 2D," J. Inf. Technol., vol. 6, no. 1, pp. 53-62, 2018.

[15] N. Sasmita, A. Pramesti, and I. D. Wijaya, "Visual Heart Anatomy," Pros. Semin. Inform. Apl. Polinema 2015, pp. 183-185, 2015. 